\title{
Body condition and insulin resistance interactions with periparturient gene expression in adipose tissue and lipid metabolism in dairy cows
}

\author{
P. Karis, ${ }^{1 *} \odot$ H. Jaakson, ${ }^{1} \odot$ K. Ling, ${ }^{1} \odot$ R. M. Bruckmaier, ${ }^{2} \odot$ J. J. Gross, ${ }^{2} \odot$ P. Pärn, ${ }^{3}$ T. Kaart, ${ }^{3} \oplus$ and M. Ots ${ }^{1} \oplus$ \\ ${ }^{1}$ Chair of Animal Nutrition, Institute of Veterinary Medicine and Animal Sciences, Estonian University of Life Sciences, 51006 Tartu, Estonia \\ ${ }^{2}$ Veterinary Physiology, Vetsuisse Faculty, University of Bern, $\mathrm{CH}-3001$, Switzerland \\ ${ }^{3}$ Chair of Animal Breeding and Biotechnology, Institute of Veterinary Medicine and Animal Sciences, Estonian University of Life Sciences, \\ 51014 Tartu, Estonia
}

\begin{abstract}
Adipose tissue plays an important role in a cow's ability to adapt to the metabolic demands of lactation, because of its central involvement in energy metabolism and immunity. High adiposity and adipose tissue resistance to insulin are associated with excessive lipid mobilization. We hypothesized that the response to a glucose challenge differs between cows of different body condition $21 \mathrm{~d}$ before and after calving and that the responses are explainable by gene expression in subcutaneous adipose tissue (SAT). In addition, we aimed to investigate insulin resistance with gene expression in SAT and lipid mobilization around parturition. Multiparous Holstein cows were grouped according to body conditions score (BCS) 4 wk before calving, as follows: $\mathrm{BCS} \leq 3.0=$ thin $(\mathrm{T}, \mathrm{n}=14)$; BCS 3.25 to $3.5=$ optimal $(\mathrm{O}, \mathrm{n}=14)$; $\mathrm{BCS} \geq 3.75=$ over-conditioned (OC, $\mathrm{n}=14)$. We collected SAT on $\mathrm{d}-21$ and $\mathrm{d} 21$ relative to calving. A reverse-transcriptase quantitative (RT-q) PCR was used to measure gene expression related to lipid metabolism. One hour after the collection of adipose tissue, an intravenous glucose tolerance test was carried out, with administration of $0.15 \mathrm{~g}$ of glucose per $\mathrm{kg}$ of body weight (with a $40 \%$ glucose solution). Once weekly from the first week before calving to the third week after calving, a blood sample was taken. The transition to lactation was associated with intensified release of energy stored in adipose tissue, a decrease in the lipogenic genes lipoprotein lipase $(L P L)$ and diacylglycerol O-acyltransferase 2 (DGAT2), and an increase in the lipolytic gene hormone-sensitive lipase (LIPE). On d -21, compared with T cows, OC cows had lower mRNA abundance of $L P L$ and DGAT2, and the latency of fatty acid response after glucose infusion was also longer ( 8.5 vs. $23.3 \mathrm{~min}$ ) in OC cows. Cows with higher
\end{abstract}

Received July 31, 2019.

Accepted December 2, 2019.

*Corresponding author: priit.karis@emu.ee insulin area under the curve on $\mathrm{d}-21$ had concurrently lower $L P L$ and DGAT2 gene expression and greater concentration of fatty acids on $\mathrm{d}-7, \mathrm{~d} 7$, and $\mathrm{d} 14$. In conclusion, high adiposity prepartum lowers the whole-body lipid metabolism response to insulin and causes reduced expression of lipogenic genes in SAT 3 weeks before calving. In addition, more pronounced insulin release after glucose infusion on $\mathrm{d}-21$ is related to higher lipid mobilization around calving, indicating an insulin-resistant state, and is associated with lower expression of lipogenic genes in SAT.

Key words: body condition score, insulin resistance, dairy cow, adipose tissue metabolism

\section{INTRODUCTION}

Dairy cows' physiological adaption to lactation has been extensively researched in recent years, as its success is crucial for the overall lactation period. Nevertheless, the transition to lactation remains the most critical period in the production cycle of dairy cows, due to the risk of excessive lipid mobilization and of disease. Adipose tissue plays an important role in a cow's ability to adapt to her new physiological state, because of its central involvement in energy metabolism and immunity (Contreras and Sordillo, 2011). The volume of subcutaneous adipose tissue (SAT) can be accurately quantified through BCS, and under- or overconditioned cows at calving face greater risks of health problems (Roche et al., 2009). Physiological processes before parturition are assumed to blunt the insulin response in insulin-sensitive tissues, causing insulin resistance (IR) during transition to lactation, to support energy and nutrient flow to the mammary gland (De Koster and Opsomer, 2013). Insulin is an important antilipolytic hormone, and therefore its low concentration in plasma, or a blockage in its signal transduction in adipose tissue, causes intensified lipolysis that may result in lipotoxicity due to the high concentration of fatty acids in plasma. It has been argued that IR in adipose tissue facilitates high fatty acid release postpartum 
(Bell, 1995). However, this concept has recently been questioned, as evidence from both clamp (Weber et al., 2016; Grossen-Rösti et al., 2018) and mRNA (Ji et al., 2012) studies have failed to support this idea. On the other hand, a common finding in intravenous glucose tolerance test (IVGTT) studies is a slight or no difference in glucose area under the curve (AUC), but considerable increase in insulin AUC for over-conditioned compared with adequately conditioned cows (Bogaert et al., 2018; Jaakson et al., 2018) and over-fed cows prepartum (Holtenius et al., 2003), which supports the IR hypothesis. In addition, we previously (Jaakson et al., 2018) demonstrated lower glucose transport protein 4 (GLUT4) concentrations in the adipose tissue of overconditioned cows 3 weeks before parturition. De Koster et al. (2015) also found decreased insulin sensitivity of glucose metabolism for over-conditioned cows. On the other hand, at physiological concentrations of insulin its antilipolytic effect remained intact (De Koster et al., 2015, 2016). However, cows with excessive adipose tissue at parturition are well known to release more stored lipids (Roche et al., 2009). These findings highlight the complexity of interactions involved in insulin signaling in adipose tissue and the need for additional studies to elucidate the causes of excessive lipid mobilization after parturition.

In the present study, we hypothesized that the response to a glucose challenge differs between cows with different body condition $21 \mathrm{~d}$ before and after calving, and these differences are explainable by gene expression in SAT. We aimed to use the IVGTT to assess the effect of insulin on lipid metabolism in relation to the volume of SAT prepartum, and to investigate the expression of genes related to lipolysis and lipogenesis in SAT. In addition, we aimed to associate IR with gene expression in SAT and lipid mobilization around parturition.

\section{MATERIALS AND METHODS}

\section{Experimental Design}

In this experiment, we followed the European Council Directive regarding the protection of animals and the Estonian Animal Protection Act. The study was approved by the Committee for Conducting Animal Experiments at the Estonian Ministry of Agriculture. Detailed descriptions of the experimental design, animals, feeds, and methods have been reported previously (Jaakson et al. 2018). In brief, the study was carried out on the experimental farm of the Estonian University of Life Sciences (Tartu, Estonia), with a herd size of 120 cows and a mean annual milk yield of 9,200 $\mathrm{kg} /$ cow. Over 2 consecutive years (2013 to 2015), 42 indoor-housed multiparous Estonian Holstein cows were assigned to 3 experimental groups on the basis of BCS $28 \mathrm{~d}$ before expected calving $(\mathrm{d}-28)$ as follows: $\mathrm{BCS} \leq 3.0(2.25$ to 3.00$)=$ thin $(\mathbf{T}, \mathrm{n}=14)$; BCS of 3.25 to $3.5=$ optimal $(\mathbf{O}, \mathrm{n}=14) ; \mathrm{BCS} \geq 3.75(3.75$ to 4.50$)=$ over-conditioned $(\mathbf{O C}, \mathrm{n}=14)$. We assessed BCS fortnightly, according to the method described by Edmonson et al. (1989), from drying-off until d -28 prepartum. Cows whose BCS did not change in this period were enrolled, in a blocked design with each block consisting of 3 cows, 1 from each group. After calving, BCS was assessed weekly. The average parity of the cows was as follows: $\mathrm{T}=2.6(9$ parity 2,3 parity 3,1 parity 4,1 parity 5$) ; \mathrm{O}=3.2(5$ parity 2,4 parity 3 , 3 parity 4, 1 parity 5,1 parity 6 ); $\mathrm{OC}=3.7$ (1 parity 2, 6 parity 3,4 parity 4,2 parity 5,1 parity 6$)$. On d -28 , cows were removed from the dry-cow barn to tiestall housing, to adjust to experimental conditions. After calving, from the seventh milking onward, cows were housed in a freestall barn with a milking parlor. Cows were milked twice daily.

Diets and their ingredients and chemical compositions are presented in Table 1. Cows were fed TMR ad libitum twice daily, at 0530 and $1430 \mathrm{~h}$. Diets were calculated according to Estonian feeding recommendations: ME according to Oll (1995), MP as described by Kärt et al. (2002).

\section{BCS Loss, Blood Sampling, Glucose Tolerance Test, and Laboratory Analyses}

To calculate BCS loss, weekly BCS measurements were modeled as described by Thorup et al. (2012). The loss was defined as the total BCS loss during the first 21 DIM.

Blood samples were taken on $\mathrm{d}-7( \pm 2.6$; mean $\pm \mathrm{SD}), \mathrm{d} 7( \pm 0.9), \mathrm{d} 14( \pm 0.8)$, and $\mathrm{d} 21( \pm 1.0)$ at approximately $1000 \mathrm{~h}$. Blood was drawn from the coccygeal vein into vacuum tubes containing Li-heparin (Vacuette, Greiner Bio-One International GmbH, Kremsmünster, Austria), centrifuged $(5,000 \times g, 15$ $\min , 4^{\circ} \mathrm{C}$ ), and stored at $-80^{\circ} \mathrm{C}$. We used an enzymaticcolorimetric method (cat. no. FA 115; Randox Laboratories Ltd., Crumlin, UK) to analyze fatty acids, and BHB was analyzed using the kinetic-enzymatic UV method (cat. no. RB 1007; Randox Laboratories) with an automatic analyzer (ERBA XL300; Randox Laboratories). The inter-assay CV were $8.3 \%$ and $6.1 \%$, and intra-assay CV were $6.1 \%$ and $5.7 \%$ for fatty acids and $\mathrm{BHB}$, respectively.

The IVGTT was carried out on $\mathrm{d}-21$ and on $\mathrm{d} 21$ relative to calving. Relative to the start of jugular vein infusion of a $0.15 \mathrm{~g} / \mathrm{kg}$ of BW glucose (40\%) solution, blood samples were collected at -5 (basal) , 5, 10, 20, 30, 40, 50, and $60 \mathrm{~min}$. Blood samples were centrifuged, 
Table 1. Diet ingredients and chemical composition (mean $\pm \mathrm{SD}$ ) of TMR diets

\begin{tabular}{|c|c|c|c|c|c|}
\hline Item & \multicolumn{5}{|c|}{ Diet } \\
\hline Grass silage & $955 \pm 81$ & $599 \pm 71$ & $604 \pm 72$ & $460 \pm 49$ & $384 \pm 37$ \\
\hline Hay & $33.6 \pm 81$ & $28.3 \pm 69$ & $28.6 \pm 70$ & $20.3 \pm 49$ & $15.6 \pm 37$ \\
\hline Barley meal & - & $301 \pm 10$ & $303 \pm 10$ & $309 \pm 0.1$ & $296 \pm 0.2$ \\
\hline Anionic mineral feed ${ }^{3}$ & - & $10.4 \pm 0.2$ & - & - & - \\
\hline Limestone & - & $6.26 \pm 0.2$ & - & $4.29 \pm 0.0$ & $4.41 \pm 0.7$ \\
\hline Sodium chloride & - & - & $5.78 \pm 0.1$ & $4.72 \pm 0.0$ & $4.40 \pm 0.0$ \\
\hline $\mathrm{DM}$ of diet, $\mathrm{g} / \mathrm{kg}$ & $348 \pm 78$ & $435 \pm 64$ & $433 \pm 64$ & $483 \pm 53$ & $511 \pm 45$ \\
\hline \multicolumn{6}{|l|}{ Chemical composition } \\
\hline $\mathrm{CP}, \mathrm{g} / \mathrm{kg}$ of DM & $131 \pm 10.5$ & $144 \pm 7.2$ & $145 \pm 7.3$ & $161 \pm 5.6$ & $169 \pm 4.8$ \\
\hline $\mathrm{P}, \mathrm{g} / \mathrm{kg}$ of $\mathrm{DM}$ & $3.42 \pm 0.4$ & $4.06 \pm 0.2$ & $4.03 \pm 0.2$ & $4.48 \pm 0.2$ & $4.77 \pm 0.2$ \\
\hline
\end{tabular}

${ }^{1}$ Composition (as-fed basis): $170 \mathrm{~g} / \mathrm{kg}$ of Ca; $50 \mathrm{~g} / \mathrm{kg}$ of P; $30 \mathrm{~g} / \mathrm{kg}$ of Na; $140 \mathrm{~g} / \mathrm{kg}$ of Mg; $30 \mathrm{~g} / \mathrm{kg}$ of S; $1,000 \mathrm{mg} / \mathrm{kg}$ of Cu; $4,500 \mathrm{mg} / \mathrm{kg}$ of $\mathrm{Zn} ; 4,000 \mathrm{mg} / \mathrm{kg}$ of $\mathrm{Mn} ; 40 \mathrm{mg} / \mathrm{kg}$ of Se; $50 \mathrm{mg}$ of Co; $200 \mathrm{mg}$ of I; 800,000 IU/ $\mathrm{kg}$ of vitamin A; 190,000 IU $/ \mathrm{kg}$ of vitamin D; and 8,000 IU/kg of vitamin E.

${ }^{2}$ Composition (as-fed basis): $150 \mathrm{~g} / \mathrm{kg}$ of Ca; $35 \mathrm{~g} / \mathrm{kg}$ of P; $75 \mathrm{~g} / \mathrm{kg}$ of Na; $90 \mathrm{~g} / \mathrm{kg}$ of Mg; $1 \mathrm{~g} / \mathrm{kg}$ of S; 4,000 mg/kg of Cu; 6,667 mg/kg of Zn; $6,452 \mathrm{mg} / \mathrm{kg}$ of Mn; $94 \mathrm{mg} / \mathrm{kg}$ of Se; $109 \mathrm{mg}$ of Co; 650,000 IU $/ \mathrm{kg}$ of vitamin A; 150,000 IU $/ \mathrm{kg}$ of vitamin D; and 4,000 IU/ $/ \mathrm{kg}$ of vitamin E.

${ }^{3}$ Composition (as-fed basis): $9 \mathrm{~g} / \mathrm{kg}$ of Ca; $1 \mathrm{~g} / \mathrm{kg}$ of P; $5 \mathrm{~g} / \mathrm{kg}$ of Na; $100 \mathrm{~g} / \mathrm{kg}$ of Mg; 1,000 mg/kg of Cu; 5,000 mg/kg of Zn; 2,000 mg/kg of Mn; $27 \mathrm{mg} / \mathrm{kg}$ of Se; $40 \mathrm{mg}$ of Co; $100 \mathrm{mg}$ of I; 1,000,000 IU $/ \mathrm{kg}$ of vitamin A; 60,000 IU $/ \mathrm{kg}$ of vitamin D; 10,000 mg/kg of vitamin E; and $100,000 \mu \mathrm{g} / \mathrm{kg}$ of biotin.

and plasma stored at $-80^{\circ} \mathrm{C}$ until analyzed for fatty acids and BHB, as described above. Decreases of fatty acids and BHB were calculated as the difference between basal and minimum concentrations and expressed as percentage from the basal concentration. Latency was defined as the point at which the second-order polynomial fitted to fatty acid values between minutes 5 and 60 , expressed as the percentage of basal fatty acids, crossed the $\mathrm{x}$-axis. If values were lower than the average infusion time of $2 \mathrm{~min}$, then the latency period length was expected to be $2 \mathrm{~min}$. The calculations and values of insulin AUC have been previously reported (Jaakson et al., 2018).

\section{Sampling and Processing of Adipose Tissue}

We took SAT biopsies before the IVGTT procedures, from the pin bone region of each cow after local anesthesia [Lidocaine-Grindeks (Riga, Latvia) $20 \mathrm{mg} /$ $\mathrm{mL}$ injection solution] under aseptic conditions on $\mathrm{d}$ -21 and d 21 relative to calving. A 2-cm skin incision was made, and a tissue sample of about $3 \mathrm{~g}$ was collected, flushed with physiological saline, mounted into screw-cup tubes (Axygen, Corning Inc., Corning, NY), immediately frozen in liquid nitrogen, and stored at $-80^{\circ} \mathrm{C}$. The skin incision was closed with stitches, and the wound was disinfected and covered with an aluminum spray for mechanical protection.

For RNA analyses, adipose tissue was homogenized using the FastPrep-24 (116004500, MP Biomedicals, Illkirch-Graffenstaden, France) with a Metal Bead Lysing Matrix (cat. no. 6925-050; MP Biomedicals) in QIAzol Lysis Reagent (cat. no. 79306, Qiagen GmbH, Hilden, Germany), and total RNA was isolated with the RNeasy Lipid Tissue Mini Kit (cat. no. 74804, Qiagen). We determined RNA integrity using a 2100 Bioanalyzer (Agilent Technologies, Santa Clara, CA) and RNA 6000 Nano kit (Agilent Technologies), and it was found to range between 6.7 and 8.0. We determined RNA concentrations with the Qubit RNA HS Assay Kit (Thermo Fisher Scientific, Waltham, MA). Total RNA, extracted from tissues, was stored at $-80^{\circ} \mathrm{C}$ until cDNA synthesis using the QuantiTect Reverse Transcription Kit (cat. no. 205311, Qiagen). Synthesized cDNA was stored at $-20^{\circ} \mathrm{C}$ until used for PCR.

Multiplex quantitative real-time PCR was carried out on one 384-well plate for each target gene together with reference gene in 4 replicates using the TaqMan Gene Expression Master Mix (cat. no. 4369016, Thermo Fisher Scientific) with the ViiA 7 Real-Time PCR System 
(Applied Biosystems, Thermo Fisher Scientific). All primers and probes were from Thermo Fisher Scientific. We used GAPDH (Assay ID: Bt03210913_g1) as a reference gene for normalization of mRNA expression levels of the genes leptin (LEP; assay ID: Bt03211909_m1), lipoprotein lipase ( $L P L$; assay ID: Bt03240499_m1), solute carrier family 27 member 1 (SLC27A1, fatty acid transport protein 1; assay ID: Bt03252013_m1), diacylglycerol O-acyltransferase 2 (DGAT2; assay ID: Bt03259839_m1), and hormone-sensitive lipase [ $L I P E$ (HSL); assay ID: Bt03253691_m1). Cycle threshold (Ct) values were used to calculate relative gene expression levels using the $\Delta \mathrm{Ct}$ method. For statistical analysis, we used the mean of 4 replicates' Ct values.

\section{Statistical Analysis}

Before statistical analysis, the relative mRNA concentrations of $L E P$ and $S L C 27 A 1$ were multiplied by 100; LIPE, LPL, and DGAT2 were multiplied by 10, to avoid negative values after logarithmic transformation. Statistical analyses were performed with the software $\mathrm{R}$ (version 3.3.1; R Foundation for Statistical Computing, Vienna, Austria). Pearson correlation coefficients were calculated to investigate the relationships between fatty acids and mRNA, between fatty acids and insulin AUC, between mRNA and insulin AUC, and between insulin AUC and BCS loss. To estimate the effect of BCS group and time on the dependent variables, a mixed linear model was fitted, considering the fixed effects of BCS group, time of IVGTT, their interaction, and the confounding factors of parity, relative breeding value for milk production, and presence of health disorders, and random effects of block and cow nested to block. Disorders occurred only in the postpartum period and were dichotomized: (1) no occurrence of disorders or (2) an occurrence of any clinical disorder. The complete list of disorders has been reported earlier (Jaakson et al., 2018). Pre- and postpartum IVGTT data were modeled separately. Thus, the effects of time of IVGTT, time of IVGTT and group interaction, and cow were excluded from the model for postpartum data, and in addition, the presence of health disorders for prepartum data. Modeling was performed with the function lmer in the $\mathrm{R}$ package lme4, and the least squares means (LSM, also called marginal or model-based means) were estimated with the function lsmeans. The pairwise comparison of LSM was performed with the function contrast. The Tukey method was used to adjust $P$-values for multiple testing. Two analyses were performed for variables that were not normally distributed: first the models were fitted and LSM were estimated on an arithmetic scale; subsequently $P$-values were estimated, fitting the same models on log-transformed values. Statistical significance was declared at $P<0.05$ and tendency at $P<$ 0.1 .

\section{RESULTS}

\section{Glucose Tolerance Test}

In general, the infusion of glucose, after the initial latency, was associated with a decrease in fatty acid and BHB concentrations before and after calving (Figure 1). The basal concentrations and proportional decrease of fatty acids on $\mathrm{d}-21$ were similar between groups, but, between 10 and $60 \mathrm{~min}$, group $\mathrm{T}$ differed from the OC group $(P<0.05)$, and, between 20 and 50 min, group $\mathrm{O}$ differed from OC $(P<0.05)$. Latency of fatty acids was the shortest in group T compared with groups $\mathrm{O}(P<0.05)$ and $\mathrm{OC}(P<0.01$; Table 2$)$. On $\mathrm{d}$ 21 , the dynamics were similar between groups (Figure 1), but a difference appeared at 20 and 30 min between groups $\mathrm{T}$ and $\mathrm{OC}(P<0.05)$.

The concentration of BHB on $\mathrm{d}-21$ in group $\mathrm{T}$, with the highest values throughout the IVGTT, tended to differ from group $\mathrm{O}$ at $40 \mathrm{~min}(P=0.08)$ and differed from group $\mathrm{O}(P<0.05)$ at 50 min. On d 21 the BHB concentration in the OC group only tended to differ from group $\mathrm{T}(P=0.09)$ at min 10 , where $\mathrm{OC}$ was higher (Figure 1). Insulin AUC on $\mathrm{d}-21$ in group $\mathrm{T}$ with the lowest value differed from group OC with the highest value $(P<0.01)$.

\section{Gene Expression}

Time was a significant factor for all of the studied genes' mRNA abundance $(P<0.01$, Figure 2$)$. Abundance was higher on $\mathrm{d} 21$ than on $\mathrm{d}-21$ for $L I P E$ and SLC27A1 and lower for LEP, DGAT2, and $L P L$. We found a group effect for DGAT2 $(P<0.05)$ and $L P L(P<0.01)$ mRNA abundance. On $\mathrm{d}-21$, the OC group had the lowest DGAT2 and $L P L$, and this group's mRNA abundance differed from group $\mathrm{T}(P<$ $0.05)$, which had the lowest expression. For $L P L$, analysis also revealed a tendency to differ between groups $\mathrm{T}$ and $\mathrm{O}(P=0.07)$. No differences were found between experimental groups on d 21 (Figure 2).

\section{Pearson Correlations}

In the calculation of Pearson correlations, the BCS groups were not differentiated. The Pearson correlation coefficients of gene expression and insulin AUC on d -21 with fatty acids on $\mathrm{d}-7$ and $\mathrm{d} 7$ are presented in Figure 3. Insulin AUC on $\mathrm{d}-21$ with gene expressions 
Table 2. Characteristics describing the dynamics of metabolites during intravenous glucose tolerance test

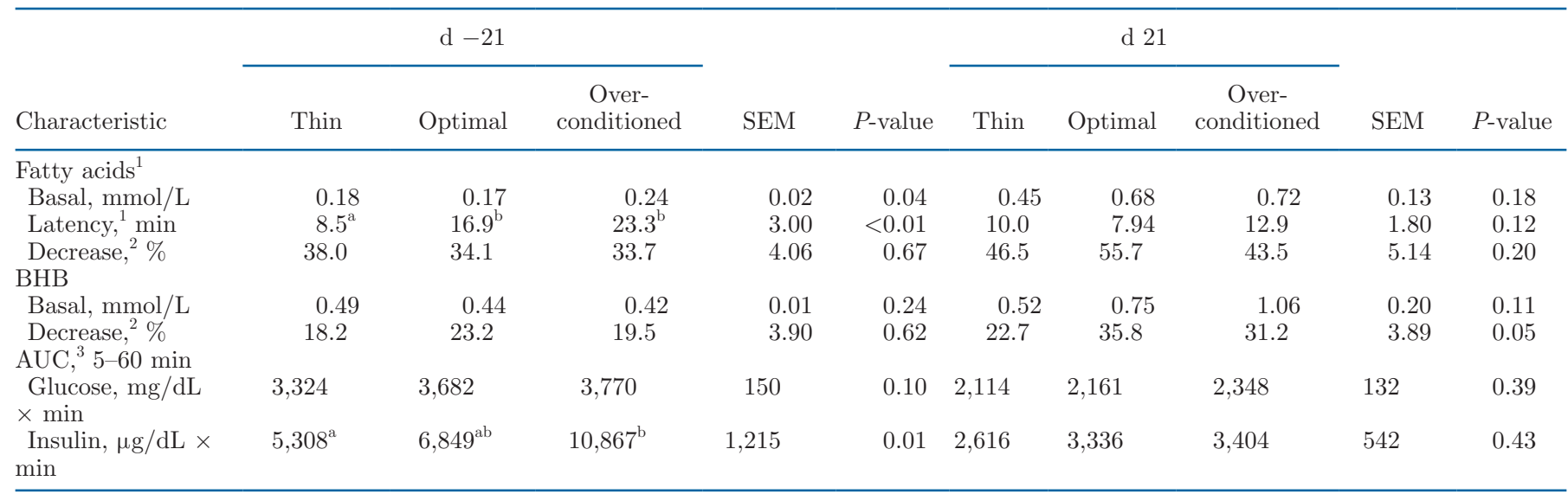

$\overline{\mathrm{a}, \mathrm{b}}$ Values within a row with different superscripts are significantly different $(P<0.05)$.

${ }^{1}$ The time from the start of glucose infusion until the concentration dropped below the basal value.

${ }^{2}$ The difference between basal and minimum, expressed as a percentage of the basal value.

${ }^{3}$ Area under the curve.

and BCS loss are presented in Figure 4. The average concentrations of fatty acids were as follows (mean \pm $\mathrm{SD}): \mathrm{d}-7,0.13 \pm 0.071 \mathrm{mmol} / \mathrm{L} ; \mathrm{d} 7,0.59 \pm 0.362$ $\mathrm{mmol} / \mathrm{L} ; \mathrm{d} 14,0.49 \pm 0.302 \mathrm{mmol} / \mathrm{L} ; \mathrm{d} 21,0.53 \pm 0.443$ $\mathrm{mmol} / \mathrm{L}$. We observed a positive correlation between insulin AUC on $\mathrm{d}-21$ and plasma fatty acids on $\mathrm{d}$ $-7, \mathrm{~d} 7(\mathrm{r}=0.49$ and 0.55 , respectively; $P<0.01$
Figure 3$)$, and $\mathrm{d} 14(\mathrm{r}=0.39 ; P<0.05$; data not shown). The mRNA abundance of $L P L$ on $\mathrm{d}-21$ was negatively correlated with fatty acids on $\mathrm{d}-7$ and $\mathrm{d}$ 7 ( $\mathrm{r}=-0.32$ and -0.40 , respectively; $P<0.05$ ), and the mRNA abundance of DGAT2 on $\mathrm{d}-21$ tended to be negatively correlated with fatty acids on $\mathrm{d}-7(\mathrm{r}=$ $-0.31 ; P=0.06)$ and negatively correlated on $\mathrm{d} 7(\mathrm{r}=$
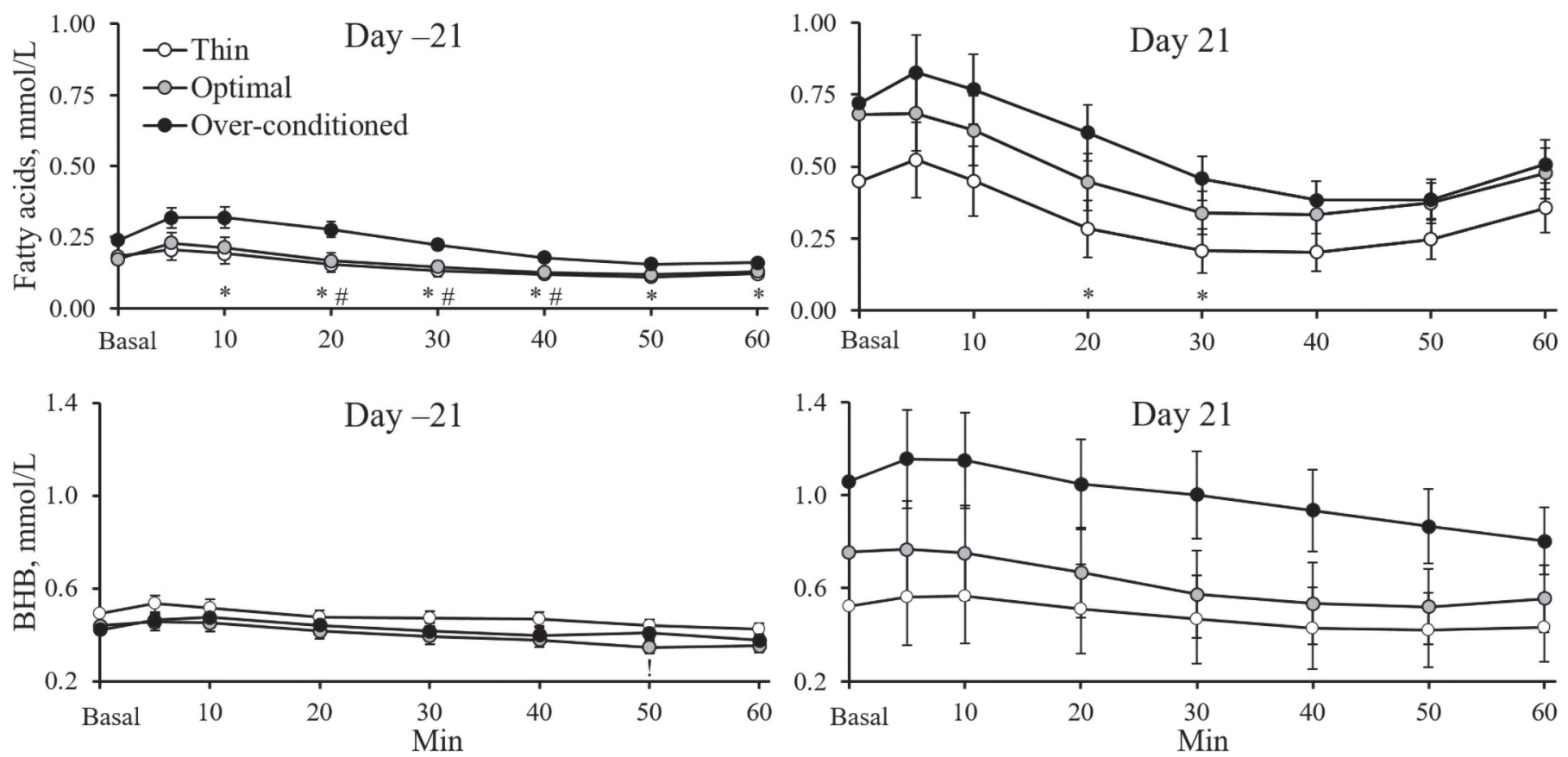

Figure 1. Concentrations of fatty acids and BHB during the i.v. glucose tolerance test on $\mathrm{d}-21$ and 21 relative to calving in multiparous Holstein cows, grouped according to BCS on d -28 as follows: $\leq 3.0=$ Thin; 3.25 to $3.5=$ Optimal; $\geq 3.5=$ Over-conditioned $(\mathrm{n}=14$ each). Values are expressed as LSM \pm SEM. *Indicates a difference $(P \leq 0.05)$ between Thin and Over-conditioned groups; ! indicates difference between Thin and Optimal groups; and \# indicates difference between Optimal and Over-conditioned groups. No significant difference was found between Thin and Optimal groups. 
$-0.30 ; P<0.05)$. In addition, insulin AUC on $\mathrm{d}-21$ was negatively correlated with the mRNA abundance of the lipogenic genes $L P L$ and DGAT2 ( $\mathrm{r}=-0.32$ and -0.31 , respectively; $P<0.05)$ and positively with total BCS loss during 21 DIM $(\mathrm{r}=0.48 ; P<0.01)$.

\section{DISCUSSION}

This paper is a companion paper to that of Jaakson et al. (2018), which investigated glucose metabolism in dairy cattle and reported the indices of glucose and insulin.

\section{IVGTT}

Insulin is a potent inhibitor of lipolysis; its signaling reduces the cellular concentration of cyclic AMP (cAMP) that, in turn, reduces protein kinase $\mathrm{A}$ (PKA)-mediated lipolysis (Bolsoni-Lopes and AlonsoVale, 2015). Although lipolysis was low on d -21 (low basal fatty acid concentration), insulin further repressed lipolysis, as we observed a decrease in fatty acids in all groups. We previously reported the highest insulin AUC prepartum in OC cows compared with $\mathrm{T}$ and O cows (Jaakson et al., 2018), but this did not result in enhanced fatty acid clearance. On the contrary, OC cows had higher values throughout IVGTT. The insulin peak, even in group $\mathrm{T}$ with the smallest insulin AUC (Jaakson et al., 2018), was sufficient for maximal inhibitory effect on lipolysis, according to the insulin-dose response curve calculated by De Koster et al. (2015). This explains the similar fatty acid decrease between groups. The greater fatty acid concentrations during IVGTT in the OC group on $\mathrm{d}-21$ are explainable by the positive correlation between the size of the adipocytes and the basal lipolytic rate (De Koster et al., 2016), which insulin does not control. On the other hand, it could be argued that IR might be responsible for the differences we observed during IVGTT, as high insulin AUC is an indicator of increased pancreatic insulin secretion to compensate for peripheral IR (Bogaert et al., 2018). In support of this, Salin et al. (2018) used latency of the fatty acid response after glucose infusion to assess insulin sensitivity, and latency in our study was associated with BCS group and was lowest in group T. However, little information is available on the cause of the duration of latency period. We assume that the rapid increase of glucose in plasma hinders the use of other energy sources (e.g., fatty acids, BHB), and the latency describes the time it takes for the insulin signaling network to suppress the production and increase the elimination of these substances. To conclude, OC cows had the highest levels of insulin secretion after glucose infusion, greater fatty acid values during IVGTT, and longer latency compared with thinner cows - all of which indicates that high adiposity in the prepartal period lowers the lipid metabolism response to insulin, in insulin-sensitive tissues.

The decreasing BHB concentration during the prepartum IVGTT is a result of increased glucose concentration (suppression of ketogenesis in the liver), decreased fatty acid concentration (decreased availability of substrate), and elimination of BHB from blood. The basal BHB values prepartum were low in all groups, and the dynamics after glucose infusion were similar. Even though a difference appeared at 50 min between
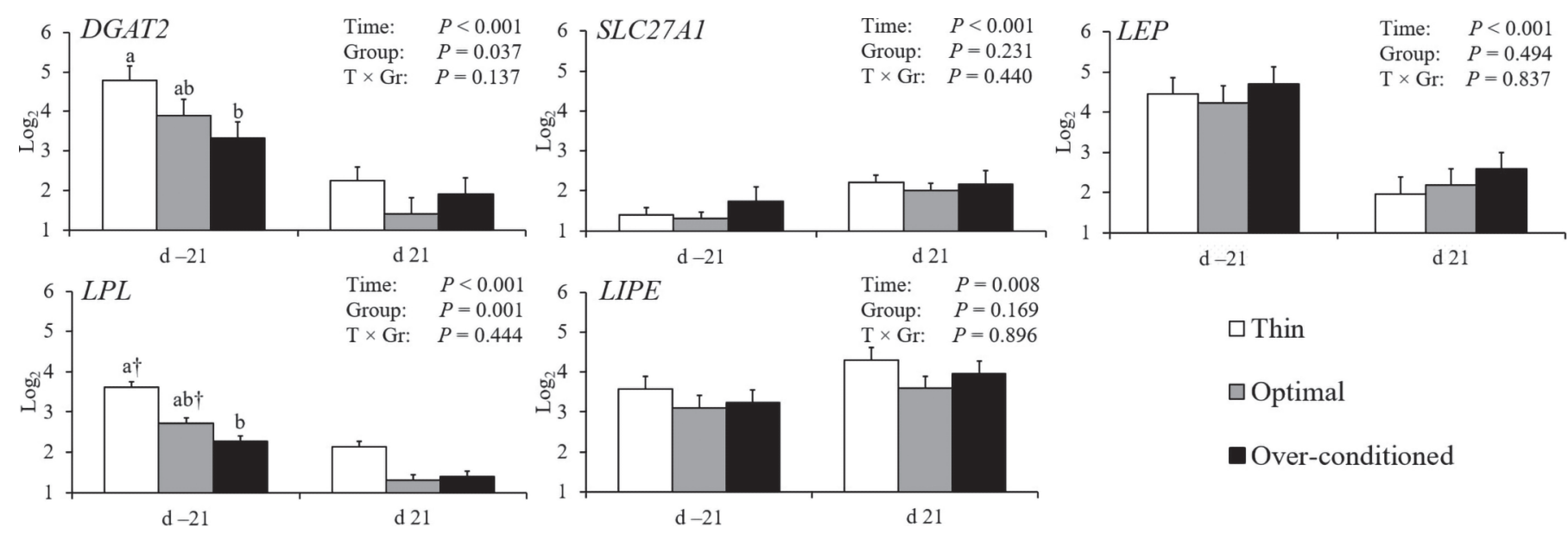

口Thin

$\square$ Optimal

口ver-conditioned

Figure 2. Expression of diacylglycerol O-acyltransferase 2 (DGAT2), solute carrier family 27 member 1 (SLC27A1), leptin (LEP), lipoprotein lipase $(L P L)$, and hormone-sensitive lipase $(L I P E)$ on d -21 and 21 relative to calving in subcutaneous adipose tissue of multiparous Holstein cows grouped according to BCS on $d-28$ as follows: $\leq 3.0=$ Thin; 3.25 to $3.5=$ Optimal; $\geq 3.5=$ Over-conditioned $(\mathrm{n}=14$ each). Values are expressed as LSM \pm SEM. Different letters $(\mathrm{a}, \mathrm{b})$ indicate difference $(P \leq 0.05)$; †indicates tendency to differ $(P \leq 0.1)$. 
groups $\mathrm{T}$ and $\mathrm{O}$ during IVGTT, we do not believe it has physiological relevance.

We observed no differences between groups in the dynamics of fatty acids after glucose infusion. This suggests that the volume of SAT does not interfere with insulin antilipolytic signal on d 21, as Weber et al. (2016) also concluded, and we have to agree with Salin et al. (2017) that the response of fatty acids after glucose infusion is driven largely by basal fatty acid concentration.

\section{Effect of Lactational Stage on SAT Gene Expression}

Previous studies indicate that lipogenesis in early lactation is mainly controlled at the transcription level, whereas control of lipolysis occurs at a posttranslational level (Khan et al., 2013). We observed significantly lower DGAT2 and LPL mRNA abundance on d 21 compared with $\mathrm{d}-21$. Therefore, potentially lower availability of lipoprotein-derived fatty acids (due to decreased $L P L$ ) and lower intracellular (re-)esterification of fatty acids to triacylglycerol (due to decreased DGAT2) may occur in adipose tissue in early lactation compared with prepartum. Van den Top et al. (2005) have also reported lower LPL protein activity postpartum. In adipose tissue, insulin positively regulates LPL transcription and enzyme activity (Kersten, 2014), whereas energy deficit (Bonnet et al., 2004) regulates them negatively.
This means that the physiological state of a dairy cow in the immediate postpartum period favors the downregulation of LPL in adipose tissue and, thus, energy partitioning toward the mammary gland.

The mRNA abundance of LIPE has been variously shown to increase (Sumner and McNamara, 2007), not to change (Sadri et al., 2010), or to decrease (Ji et al., 2012; De Koster et al., 2018) in transition from the dry period to lactation. However, the increase in phosphorylation of hormone-sensitive lipase (HSL, the protein of LIPE) has been consistently demonstrated (Mann et al., 2016; De Koster et al., 2018). This highlights the importance of post-translational modification of HSL and limits the possibility of drawing associations between lipolysis and mRNA abundance of LIPE.

Higher expression of $S L C 27 A 1$ postpartum is contrary to the changes we found for the other lipogenic pathway genes (LPL and DGAT2). This suggests that not all lipogenic genes are downregulated postpartum and that different control mechanisms may exist for the studied genes. Ji et al. (2012) also found an overall decrease in the expression of lipogenic genes postpartum, except for genes related to fatty acid uptake.

The present study showed a decrease in leptin expression postpartum that accords with the findings of Vailati-Riboni et al. (2016). In addition, Kokkonen et al. (2005) and Mann et al. (2018) observed less leptin protein in plasma. It seems that the transcription and
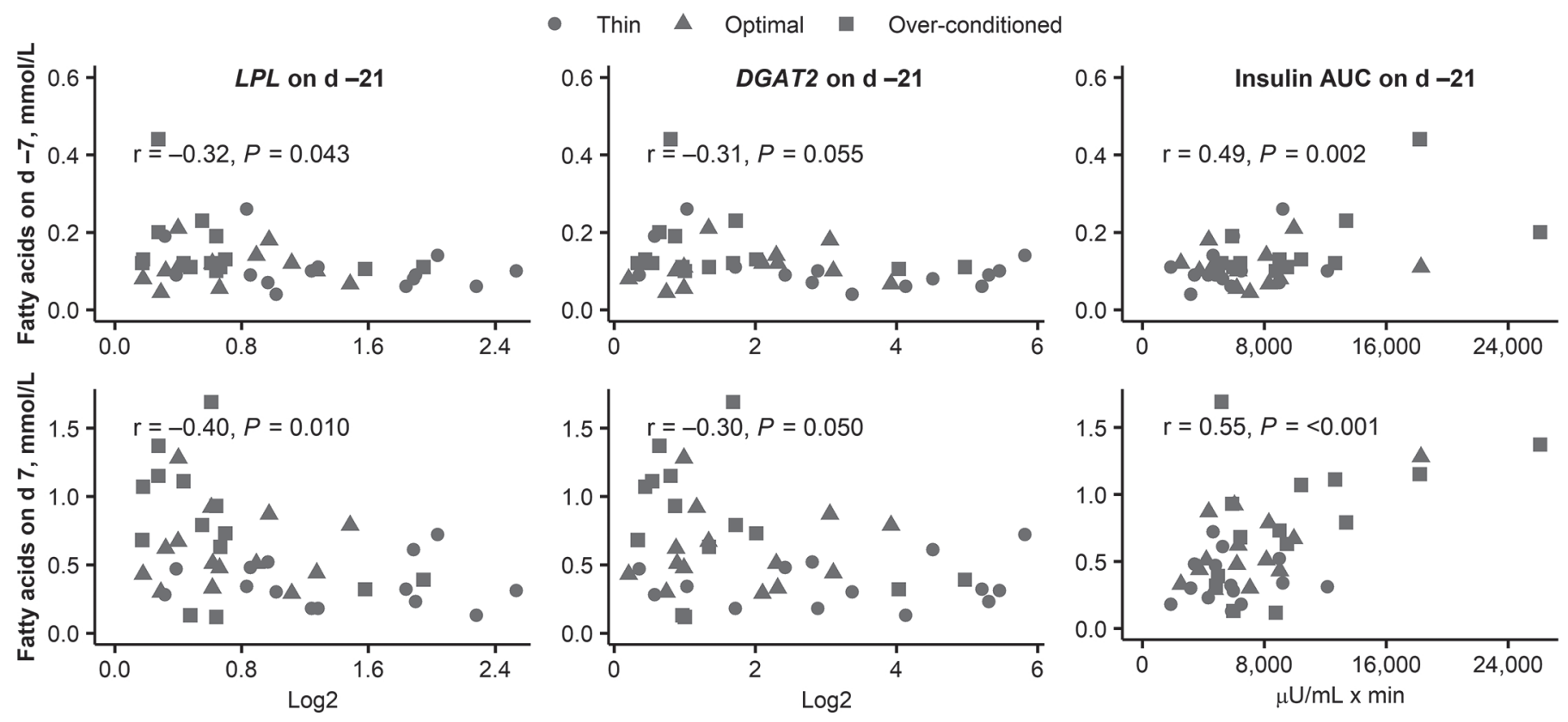

Figure 3. Pearson correlation coefficients (r) of d -21 lipoprotein lipase mRNA (LPL), diacylglycerol O-acyltransferase 2 mRNA ( DGAT2),

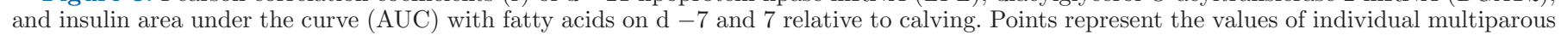
Holstein cows. 

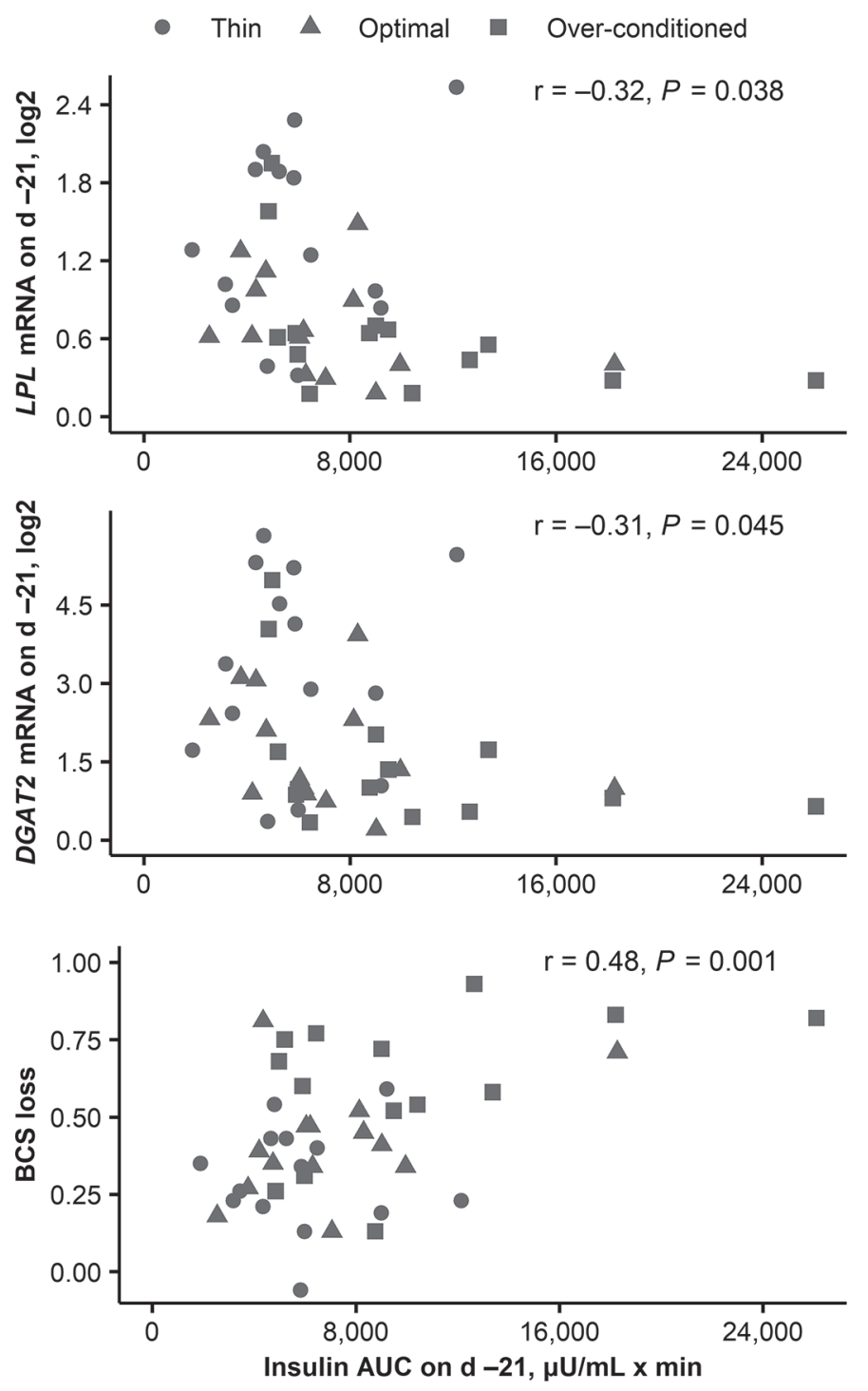

Figure 4. Pearson correlation coefficients (r) of lipoprotein lipase mRNA ( $L P L)$, diacylglycerol O-acyltransferase 2 mRNA (DGAT2), and total BCS loss in the first 21 DIM, with insulin area under the curve (AUC) on $\mathrm{d}-21$. Points represent the values of individual multiparous Holstein cows.

protein expression of leptin are both downregulated during negative energy balance.

\section{Effects of BCS on Gene Expression in SAT}

We found reduced expression of the lipogenic genes $L P L$ and DGAT2 for OC cows on d -21 , suggesting that high adiposity is associated with decreased lipogenesis in SAT. This supports the results of Alharthi et al. (2018), who found a reduced mRNA abundance of phosphoenolpyruvate carboxykinase 1, a key enzyme for glyceroneogenesis, in SAT of over-conditioned cows pre- partum and concluded that reduced re-esterification of fatty acids occurs in those cows. The $L P L$ and DGAT2 expression results may partly explain the differences in fatty acid dynamics in our study after glucose infusion prepartum. Group T cows showed a quicker reduction of fatty acids during IVGTT, which may have been a result of a quicker elimination and re-esterification of plasma fatty acids in adipose tissue.

Regarding the early postpartum period, Alharthi et al. (2018) reported higher expression of genes involved in fatty acid oxidation for over-conditioned cows on d 7 and 20 of lactation, supporting the overall notion of over-conditioned cows using more stored lipids postpartum. This agrees with the greater basal fatty acid and BHB concentrations for OC cows in our study and confirms higher lipid mobilization for OC cows on d 21. Nevertheless, we did not observe any differences in the dynamics of fatty acids and BHB during IVGTT or on the mRNA abundance of genes on $\mathrm{d} 21$, even though the BCS was different between the groups (Jaakson et al., 2018). This suggests that, in the third week of lactation, the volume of SAT is related neither to expression of the studied genes nor to insulin signaling. Therefore, neither the differences in gene expression nor insulin signaling explain the higher lipid mobilization in OC cows.

We observed neither different LEP expression between the experimental groups nor correlations between LEP and BCS (data not shown) on d -21 and 21 , even though leptin is mainly synthesized in AT and its relations to high adiposity (Chilliard et al., 2005) and to adipocyte size (Depreester et al., 2018) have been established. In agreement with our results in the prepartum period, Schoenberg et al. (2011) did not find BCS to be an important factor for LEP expression, Mann et al. (2018) reported a weak correlation between plasma leptin and BCS, and Pires et al. (2013) found elevated plasma leptin only in cows that had higher BCS compared with the OC cows in our study. As a small adipose depot (De Koster et al., 2015) the LEP expression of SAT is lower than those of other depots (Depreester et al., 2018); therefore the contribution of the expression of $L E P$ in SAT, compared to plasma leptin concentration, may be also smaller. Hormonal agents (Block et al., 2003) and energy balance (Singh et al., 2014) also regulate leptin in plasma; thus, different feeds and feeding regimens might explain the discrepancies between studies.

In the postpartum period Holtenius et al. (2003), Mann et al. (2018), and Mansouryar et al. (2018) did not find plasma leptin to be related to BCS. These results agree with our mRNA data and suggest that the volume of SAT has no effect on either the concen- 
tration of leptin in plasma or $L E P$ expression in SAT postpartum.

\section{Insulin Resistance}

Salin et al. (2017) verified the hyperbolic relationship between insulin secretion and insulin sensitivity in dairy cows, which means that a change in sensitivity will be compensated by increased insulin secretion. Therefore, we consider that insulin AUC can be used as the measure for IR.

Endocrine status at the beginning of lactation (low insulin and high growth hormone concentration), in conjunction with adrenergic signaling, favors mobilization of body lipids through increased cellular concentration of cAMP. If insulin-sensitive cells in a dairy cow are resistant to insulin, the main antagonist of adrenergic signaling, then further lipids are mobilized.

We showed that insulin AUC prepartum has a negative correlation with lipogenic gene expression in SAT. Our data also indicate that the physiological state, closely mirrored by IR status on $d-21$, carries over to the later weeks pre- and first weeks postpartum. Cows with more prominent insulin release 3 wk before parturition tend to use more body lipids in the weeks around calving, when the release of energy stored in adipose tissue is the highest. This conclusion is supported by the positive correlations between fatty acids and BCS loss with insulin AUC. Zachut and Moallem (2017) also reported that cows with high weight loss postpartum had higher insulin AUC prepartum. We found a negative correlation between the expression of lipogenic genes on $\mathrm{d}-21$ and plasma fatty acids on $\mathrm{d}$ $-7(L P L)$ and $\mathrm{d} 7$ (LPL and DGAT2). This suggests that the net result of high plasma fatty acids in early lactation is due not only to insulin's loss of ability to inhibit lipolysis but rather to a broader hindering of insulin signaling causing a combination of an increase in lipolysis and a decrease in lipogenesis. Of course, the available data do not confirm the hypothesis but are indicative; more research is warranted to elucidate the relationship between IR and lipogenesis potential.

\section{Effects of Breeding Value on Lipolysis and Lipogenesis in SAT}

Breeding value for milk production was a significant factor for $L P L$ and DGAT2 mRNA abundance in SAT in the present article and for GLUT4 mRNA abundance in SAT in the companion article (Jaakson et al., 2018). The higher the genetic merit for milk production, the lower the expression of genes responsible for bringing in (GLUT4, LPL) and accumulating energy (DGAT2) in SAT. Selecting animals only by their effects on milk production will increase adipose tissue mobilization in transition period, and, thus, specific traits of adipose tissue must be considered in order to increase the robustness of dairy cows.

\section{CONCLUSIONS}

High adiposity prepartum lowers the whole-body response to insulin and causes reduced expression of lipogenic genes in subcutaneous adipose tissue $3 \mathrm{wk}$ before calving, but its effect was not evident postpartum. Physiological state, possibly IR, which causes more prominent insulin release after glucose infusion 3 wk before parturition, is related to higher lipid mobilization up to 2 wk postpartum and is associated with lower expression of lipogenic genes in subcutaneous adipose tissue.

\section{ACKNOWLEDGMENTS}

The Estonian Ministry of Education and Research (Tartu, Estonia) supported this study (Institutional Research Grant IUT 8-1, "Fertility and Health in Dairy Cattle"). We thank Katri Pentjärv, at the Large Animal Clinic of the Estonian University of Life Sciences (Tartu, Estonia), for her invaluable help with data collection. We also thank the staff at the Feed and Metabolism Research Laboratory and the staff at the Milk Quality Research Laboratory of the Estonian University of Life Sciences, and Yolande Zbinden at the Veterinary Physiology of the University of Bern (Switzerland) for data analysis. Finally, we appreciate the contribution of David Arney, at the Chair of Animal Nutrition of the Estonian University of Life Sciences, for linguistic correction of the manuscript, and the cooperation of the staff at the Märja Dairy Research Farm (Estonian University of Life Sciences). The authors have not stated any conflicts of interest.

\section{REFERENCES}

Alharthi, A., Z. Zhou, V. Lopreiato, E. Trevisi, and J. J. Loor. 2018. Body condition score prior to parturition is associated with plasma and adipose tissue biomarkers of lipid metabolism and inflammation in Holstein cows. J. Anim. Sci. Biotechnol. 9:12. https://doi .org/10.1186/s40104-017-0221-1.

Bell, A. W. 1995. Regulation of organic nutrient metabolism during transition from late pregnancy to early lactation. J. Anim. Sci. 73:2804-2819. https://doi.org/10.2527/1995.7392804x.

Block, S., R. Rhoads, D. Bauman, R. Ehrhardt, M. McGuire, B. A. Crooker, J. Griinari, T. Mackle, W. J. Weber, M. Van Amburgh, and Y. R. Boisclair. 2003. Demonstration of a role for insulin in the regulation of leptin in lactating dairy cows. J. Dairy Sci. 86:35083515. https://doi.org/10.3168/jds.S0022-0302(03)73955-1.

Bogaert, H., J. De Koster, W. Van Den Broeck, M. Van Eetvelde, and G. Opsomer. 2018. Effects of overconditioning on pancreatic 
insulin secretory capacity, fat infiltration, and the number and size of islets in dairy cows at the end of the dry period. J. Dairy Sci. 101:11413-11420. https://doi.org/10.3168/jds.2018-14931.

Bolsoni-Lopes, A., and M. I. C. Alonso-Vale. 2015. Lipolysis and lipases in white adipose tissue - An update. Arch. Endocrinol. Metab. 59:335-342. https://doi.org/10.1590/2359-3997000000067.

Bonnet, M., Y. Faulconnier, J. Hocquette, F. Bocquier, C. Leroux, P. Martin, and Y. Chilliard. 2004. Nutritional status induces divergent variations of GLUT4 protein content, but not lipoprotein lipase activity, between adipose tissues and muscles in adult cattle. Br. J. Nutr. 92:617-625. https://doi.org/10.1079/bjn20041240.

Chilliard, Y., C. Delavaud, and M. Bonnet. 2005. Leptin expression in ruminants: Nutritional and physiological regulations in relation with energy metabolism. Domest. Anim. Endocrinol. 29:3-22. https://doi.org/10.1016/j.domaniend.2005.02.026.

Contreras, G. A., and L. M. Sordillo. 2011. Lipid mobilization and inflammatory responses during the transition period of dairy cows. Comp. Immunol. Microbiol. Infect. Dis. 34:281-289. https://doi .org/10.1016/j.cimid.2011.01.004.

De Koster, J., M. Hostens, M. Van Eetvelde, K. Hermans, S. Moerman, H. Bogaert, E. Depreester, W. Van Den Broeck, and G. Opsomer. 2015. Insulin response of the glucose and fatty acid metabolism in dry dairy cows across a range of body condition scores. J. Dairy Sci. 98:4580-4592. https://doi.org/10.3168/jds.2015-9341.

De Koster, J., R. K. Nelli, C. Strieder-Barboza, J. de Souza, A. L. Lock, and G. A. Contreras. 2018. The contribution of hormone sensitive lipase to adipose tissue lipolysis and its regulation by insulin in periparturient dairy cows. Sci. Rep. 8:13378. https://doi .org/10.1038/s41598-018-31582-4.

De Koster, J., W. Van Den Broeck, L. Hulpio, E. Claeys, M. Van Eetvelde, K. Hermans, M. Hostens, V. Fievez, and G. Opsomer. 2016. Influence of adipocyte size and adipose depot on the in vitro lipolytic activity and insulin sensitivity of adipose tissue in dairy cows at the end of the dry period. J. Dairy Sci. 99:2319-2328. https:// doi.org/10.3168/jds.2015-10440.

De Koster, J. D., and G. Opsomer. 2013. Insulin resistance in dairy cows. Vet. Clin. North Am. Food Anim. Pract. 29:299-322. https: //doi.org/10.1016/j.cvfa.2013.04.002.

Depreester, E., J. De Koster, M. Van Poucke, M. Hostens, W. Van Den Broeck, L. Peelman, G. Contreras, and G. Opsomer. 2018. Influence of adipocyte size and adipose depot on the number of adipose tissue macrophages and the expression of adipokines in dairy cows at the end of pregnancy. J. Dairy Sci. 101:6542-6555. https://doi .org/10.3168/jds.2017-13777.

Edmonson, A., I. Lean, L. Weaver, T. Farver, and G. Webster. 1989. A body condition scoring chart for Holstein dairy cows. J. Dairy Sci. 72:68-78. https://doi.org/10.3168/jds.S0022-0302(89)79081-0.

Grossen-Rösti, L., E. C. Kessler, A. Tröscher, R. Bruckmaier, and J. J. Gross. 2018. Hyperglycaemia in transition dairy cows: Effects of lactational stage and conjugated linoleic acid supplementation on glucose metabolism and turnover. J. Anim. Physiol. Anim. Nutr. (Berl.) 102:483-494. https://doi.org/10.1111/jpn.12771.

Holtenius, K., S. Agenäs, C. Delavaud, and Y. Chilliard. 2003. Effects of feeding intensity during the dry period. 2. Metabolic and hormonal responses. J. Dairy Sci. 86:883-891. https://doi.org/10 .3168/jds.S0022-0302(03)73671-6.

Jaakson, H., P. Karis, K. Ling, A. Ilves-Luht, J. Samarütel, M. Henno, I. Jõudu, A. Waldmann, E. Reimann, P. Pärn, R. M. Bruckmaier, J. J. Gross, T. Kaart, M. Kass, and M. Ots. 2018. Adipose tissue insulin receptor and glucose transporter 4 expression, and blood glucose and insulin responses during glucose tolerance tests in transition Holstein cows with different body condition. J. Dairy Sci. 101:752-766. https://doi.org/10.3168/jds.2017-12877.

Ji, P., J. Osorio, J. K. Drackley, and J. J. Loor. 2012. Overfeeding a moderate energy diet prepartum does not impair bovine subcutaneous adipose tissue insulin signal transduction and induces marked changes in peripartal gene network expression. J. Dairy Sci. 95:4333-4351. https://doi.org/10.3168/jds.2011-5079.

Kärt, O., V. Karis, and M. Ots. 2002. Mäletsejaliste proteiintoitumine ja metaboliseeruval proteiinil põhinev söötade hindamise süsteem (Protein nutrition and metabolizable protein based feed evaluation system of ruminants). Eesti Põllumajandusülikooli Loomakasvatusinstituut, Tartu, Estonia.

Kersten, S. 2014. Physiological regulation of lipoprotein lipase. Biochim. Biophys. Acta 1841:919-933. https://doi.org/10.1016/j .bbalip.2014.03.013.

Khan, M. J., A. Hosseini, S. Burrell, S. M. Rocco, J. P. McNamara, and J. J. Loor. 2013. Change in subcutaneous adipose tissue metabolism and gene network expression during the transition period in dairy cows, including differences due to sire genetic merit. J. Dairy Sci. 96:2171-2182. https://doi.org/10.3168/jds.2012-5794.

Kokkonen, T., J. Taponen, T. Anttila, L. Syrjälä-Qvist, C. Delavaud, Y. Chilliard, M. Tuori, and A. Tesfa. 2005. Effect of body fatness and glucogenic supplement on lipid and protein mobilization and plasma leptin in dairy cows. J. Dairy Sci. 88:1127-1141. https:// doi.org/10.3168/jds.S0022-0302(05)72779-X.

Mann, S., D. V. Nydam, A. Abuelo, F. A. L. Yepes, T. R. Overton, and J. J. Wakshlag. 2016. Insulin signaling, inflammation, and lipolysis in subcutaneous adipose tissue of transition dairy cows either overfed energy during the prepartum period or fed a controlled-energy diet. J. Dairy Sci. 99:6737-6752. https://doi.org/10 $.3168 /$ jds.2016-10969.

Mann, S., C. Urh, H. Sauerwein, J. J. Wakshlag, F.A. L. Yepes, T. R. Overton, and D. V. Nydam. 2018. The association of adiponectin and leptin concentrations with prepartum dietary energy supply, parity, body condition, and postpartum hyperketonemia in transition dairy cows. J. Dairy Sci. 101:806-811. https://doi.org/10 $.3168 /$ jds.2017-13752.

Mansouryar, M., H. Mirzaei-Alamouti, M. Deghhen Banadaky, H. Sauerwein, M. Mielenz, and M. O. Nielsen. 2018. Relationship between body condition score and plasma adipokines in early-lactating Holstein dairy cows. J. Dairy Sci. 101:8552-8558. https://doi .org/10.3168/jds.2017-14122.

Oll, Ü. 1995. Feeding Requirements for Livestock with Feed Tables. Vabariiklik söötmisalase uurimistöökoordineerimise komisjon, Tartu, Estonia.

Pires, J. A., C. Delavaud, Y. Faulconnier, D. Pomiès, and Y. Chilliard. 2013. Effects of body condition score at calving on indicators of fat and protein mobilization of periparturient Holstein-Friesian cows. J. Dairy Sci. 96:6423-6439. https://doi.org/10.3168/jds.2013 $-6801$.

Roche, J. R., N. C. Friggens, J. K. Kay, M. W. Fisher, K. J. Stafford, and D. P. Berry. 2009. Invited review: Body condition score and its association with dairy cow productivity, health, and welfare. J. Dairy Sci. 92:5769-5801. https://doi.org/10.3168/jds.2009-2431.

Sadri, H., R. Bruckmaier, H. Rahmani, G. Ghorbani, I. Morel, and H. A. Van Dorland. 2010. Gene expression of tumour necrosis factor and insulin signalling-related factors in subcutaneous adipose tissue during the dry period and in early lactation in dairy cows. J. Anim. Physiol. Anim. Nutr. (Berl.) 94:e194-e202. https://doi.org/ 10.1111/j.1439-0396.2010.01005.x.

Salin, S., A. Vanhatalo, K. Elo, J. Taponen, R. Boston, and T. Kokkonen. 2017. Effects of dietary energy allowance and decline in dry matter intake during the dry period on responses to glucose and insulin in transition dairy cows. J. Dairy Sci. 100:5266-5280. https: //doi.org/10.3168/jds.2016-11871.

Salin, S., A. Vanhatalo, S. Jaakkola, K. Elo, J. Taponen, R. Boston, and T. Kokkonen. 2018. Effects of dry period energy intake on insulin resistance, metabolic adaptation, and production responses in transition dairy cows on grass silage-based diets. J. Dairy Sci. 101:11364-11383. https://doi.org/10.3168/jds.2018-14728.

Schoenberg, K. M., K. L. Perfield, J. K. Farney, B. J. Bradford, Y. R. Boisclair, and T. R. Overton. 2011. Effects of prepartum 2,4-thiazolidinedione on insulin sensitivity, plasma concentrations of tumor necrosis factor- $\alpha$ and leptin, and adipose tissue gene expression. J. Dairy Sci. 94:5523-5532. https://doi.org/10.3168/jds.2011-4501.

Singh, S. P., S. Häussler, J. J. Gross, F. J. Schwarz, R. M. Bruckmaier, and H. Sauerwein. 2014. Circulating and milk adiponectin change differently during energy deficiency at different stages of lactation in dairy cows. J. Dairy Sci. 97:1535-1542. https://doi.org/10 $.3168 /$ jds.2013-7598. 
Sumner, J. M., and J. P. McNamara. 2007. Expression of lipolytic genes in the adipose tissue of pregnant and lactating Holstein dairy cattle. J. Dairy Sci. 90:5237-5246. https://doi.org/10.3168/ jds.2007-0307.

Thorup, V. M., D. Edwards, and N. C. Friggens. 2012. On-farm estimation of energy balance in dairy cows using only frequent body weight measurements and body condition score. J. Dairy Sci. 95:1784-1793. https://doi.org/10.3168/jds.2011-4631.

Vailati-Riboni, M., M. Kanwal, O. Bulgari, S. Meier, N. Priest, C. Burke, J. Kay, S. McDougall, M. Mitchell, C. Walker, M. Crookenden, A. Heiser, J. R. Roche, and J. J. Loor. 2016. Body condition score and plane of nutrition prepartum affect adipose tissue transcriptome regulators of metabolism and inflammation in grazing dairy cows during the transition period. J. Dairy Sci. 99:758-770. https://doi.org/10.3168/jds.2015-10046.

Van den Top, A. M., A. Van Tol, H. Jansen, M. J. Geelen, and A. C. Beynen. 2005. Fatty liver in dairy cows post partum is associated with decreased concentration of plasma triacylglycerols and decreased activity of lipoprotein lipase in adipocytes. J. Dairy Res. 72:129-137. https://doi.org/10.1017/s0022029905000774.

Weber, C., C. Schäff, U. Kautzsch, S. Börner, S. Erdmann, S. Görs, M. Röntgen, H. Sauerwein, R. Bruckmaier, C. Metges, B. Kuhla, and
H. M. Hammon. 2016. Insulin-dependent glucose metabolism in dairy cows with variable fat mobilization around calving. J. Dairy Sci. 99:6665-6679. https://doi.org/10.3168/jds.2016-11022.

Zachut, M., and U. Moallem. 2017. Consistent magnitude of postpartum body weight loss within cows across lactations and the relation to reproductive performance. J. Dairy Sci. 100:3143-3154. https://doi.org/10.3168/jds.2016-11750.

\section{ORCIDS}

P. Karis (1) https://orcid.org/0000-0001-5310-8232

H. Jaakson (® https://orcid.org/0000-0003-2583-2914

K. Ling ๑ https://orcid.org/0000-0002-8365-7459

R. M. Bruckmaier ( https://orcid.org/0000-0002-9374-5890

J. J. Gross @ (ttps://orcid.org/0000-0002-2578-6076

T. Kaart @ https://orcid.org/0000-0002-8936-768X

M. Ots @ https://orcid.org/0000-0002-0567-7999 